\title{
Political Elites and Urban Social Movements in Croatia: Political Opportunities of the Citizens' Initiative Srđ is Ours ${ }^{1}$
}

\author{
Nikola Zdunić ${ }^{1, *}$ \\ 1 Faculty of Political Science, University of Zagreb, Zagreb, Croatia \\ * E-Mail: nikola.zdunic5@gmail.com
}

\begin{abstract}
The Srđ je naš (Srđ is Ours) citizens' initiative was the first Right to the City movement in Croatia that was using the political strategy of local referenda against a local infrastructure project. Although more than $80 \%$ of voters in the referendum voted against the project, due to the required voter turnout the referendum was not successful. Using the initiative's official local newspaper and Internet sources about it, I analyze the political activities of the initiative. Additionally, I use McAdam's approach (1996) to understand the events through political opportunity theory. I analyze events that describe Srd is Ours' political context: the referendum law, the excluding strategies of political elites and the role of allies within political elites. Through the analysis of the political context, I argue that the Croatian political system is closed both formally and informally, and that political elites use excluding strategies towards social movements in Croatia.
\end{abstract}

\section{Keywords}

urban social movements, Srd is Ours, political opportunity, excluding strategies, political elites, local referendum, democracy

\section{Politische Eliten und urbane soziale Bewegungen in Kroatien: Politische Gelegenheiten der Bürgerinitiative Srđ ist Unser}

\section{Zusammenfassung}

Die Bürgerinitiative Srđ ist Unser (Srđ je naš) war die erste Recht-auf-die-Stadt-Bewegung in Kroatien, die einen lokalen Volksentscheid gegen ein lokales Infrastrukturprojekt als politische Strategie nutze. Obwohl mehr als 80 \% der WählerInnen gegen das Projekt stimmten, war der Volksentscheid aufgrund des unterschrittenen Quorums nicht erfolgreich. Auf der Grundlage von der offiziellen Zeitung der Initiative und von Internetquellen analysiere ich deren politische Aktivitäten. Zusätzlich arbeite ich mit McAdams (I996) Theorie der politischen Gelegenheitsstrukturen und analysiere den politischen Kontext von Srd ist Unser: den rechtlichen Rahmen, die ausschließenden Strategien der politische Eliten sowie die Rolle von Verbündeten innerhalb der Eliten. Unter Berücksichtigung des politischen Kontextes begründe ich, dass das politische System in Kroatien sowohl formell als auch informell geschlossen ist und das politische Eliten ausschließende Strategien gegenüber sozialen Bewegungen nutzen.

\section{Schlüsselwörter}

Städtische soziale Bewegungen, Srđ is Ours, politische Gelegenheitsstrukturen, ausschließende Strategien, politische Eliten, lokales Volksbegehren, Demokratie

The author has declared that no competing interests exist.

\footnotetext{
I Parts of this manuscript were previously published as a chapter in my Masters thesis Urban activism for public space: A comparative case study of "Srd je naš" and "IOO\% Tempelhofer Feld" (Nikola Zdunić (2015). Faculty of Political Science, University of Zagreb)
} 


\section{Introduction}

When the crisis of democracy coincided with economic deregulation and privatization, efforts to establish new participatory models of democracy have been put forth in Southeast Europe and in the broader region. More specifically, the neoliberal constellation of practices and ideologies led to the emergence of new democratic political movements, local initiatives, and local political parties, one of which was the Right to the City movement (Cepić/Kovačić 20I4; Mayer 2012). Right to the City movements are a major part of urban social movements in Europe, and contest the contemporary growth policies, as well as the deregulation of social and labor market policies (Mayer 2012, 68).

As Dolenec et al. (2015) argue in their presentation "Metamorphoses and Meaningfulness: The Right to the City Movement in Croatia," Eastern European Right to the City movements are active within a specific political context produced by both the radical neoliberalization of urbanism and the authoritarian elements of political elites' practices. Post-communist European cities show complex hybrid forms of development, characterized by welfare state retrenchment and structural dependency on multinational corporations' investment strategies (ibid. 3).

According to the paper, there were several phases of the development of the Right to the City movements in Croatia. The first phase started in 2005, when independent culture and youth NGOs worked together, using methods of negotiation and public pressure to accomplish their common goal of creating a multifunctional center for independent culture and youth at an abandoned factory site in Zagreb. Despite their efforts, however, they were not successful, in part due to Milan Bandić, the newly elected mayor of $\mathrm{Za}$ greb, breaking his promise to support the project (ibid. 7). The second and the third phases of the development of the Right to the City movements in Croatia lasted from 2006 to 20IO. They are characterized by cooperation between the Right to the City activists and the established environmental NGO Green Action. Together, they formed the initiative We won't give Varšavska. Opposing the process of neoliberalization of urbanism in Zagreb, the movement chose to protest against the project "Flower Passage," a commercial and residential complex with an underground garage in a public pedestrian area, which was, despite protests, built on the site of a I9th century building and the adjacent courtyard in downtown Zagreb. The fourth phase of the Right to the City movements in Croatia was marked by activities organized by the Urban Planning Forum-a network consisting of activists and urban movements in Croatia (ibid. I3). These included the citizens' initiative I love Pula-for Muzil, backed by the NGO Green Istria, which aimed to protect the former military peninsula in Pula from privatization (Biliškov 2013), and the initiative For Marjan in Split, supported by the organization Društvo Marjan, aiming to prevent the implementation of constructional projects in the largest park in Split (H-alter.org 20I3; Nikolić 2OII). Srdis Ours was in fact another activity co-organized by the Urban Planning Forum. It was formed by local activists in 20I0, with support from more experienced Right to the City and Green Action activists, who worked with the movement We won't give Varšavska. Their assistance consisted mostly of help with media visibility, sharing of know-how, and financial support. Srd is Ours, along with other activists, protested against the construction of a private golf resort with villas and apartments on the hill Srd, which is right above the historic center of Dubrovnik (Dolenec et al. 2015, I3). This resort project was a multimillion investment funded by Israeli entrepreneur Aaron Frankel and the company Razvoj golf [Development Golf] (Ćimić 20IO). As a political strategy of exerting pressure on the city government, the most important action of Srd is Ours was the push for the local referendum against the construction of the golf resort on Srd. Although more than $80 \%$ of those who voted in the referendum were against the Urban Development Plan, the referendum was not successful, as it failed to satisfy the obligatory $50 \%$ voter turnout, mandated by the law regulating the referendum in Croatia. (Srd is Ours 20I4, 5; Croatian Government 2016).

Following the failed referendum, in $2013 \mathrm{Srd}$ is Ours activists formed a national alliance with trade unions and other civil society organizations and started the campaign We won't give our highways. Dolenec et al. (2015) named this the beginning of the fifth phase of the Right to the City movement in Croatia. In 2015 the national alliance started a referendum campaign to prevent the center-left government from monetizing the Croatian highway infrastructure. The national alliance successfully collected signatures for the referendum. Even though the Constitutional Court of Croatia later invalidated the referendum as unconstitutional, the government stopped the process of monetization (ibid.). Recently, activists and trade unions from the national alliance We won't give our highways have formed the initiative We won't give Ours, which aims to create new models of public ownership for publicly owned companies and commons as well as to prevent their further privatization. Several Srd is Ours activists were also involved in creating this initiative (Mrakovčić 20I6).

\section{Srđ is Ours' Activities and Political Strategies}

Activities and political strategies of Srd is Ours can be categorized into three main phases - the period before the referendum, the period during the referendum campaign, and the period after the referendum campaign. 
Srđ is Ours' Activities and Political Strategies before the Referendum

During the first phase, Srd is Ours' main strategy was to inform citizens of Dubrovnik and Croatia about possible utilizations of Srd. The initiative's position was that Srd should be used in the public interest and that the private infrastructural project of building the golf resort exclusively serves political and economic elites' private interests. Additionally, Srd is Ours pointed to the neoliberal ideology and undemocratic processes that were becoming more and more evident among local politicians in Dubrovnik (Srd is Ours 2011a, 2). Srd is Ours' primary activities included the organization of press conferences, public debates, and a protest on the hill Srd, as well as networking with other activists, volunteers and associations. They also created media content that was disseminated through their web page, their Facebook page and their printed newspaper.

In 20IO Srdis Ours organized its first press conference to present their work to the wider public. They argued against the golf resort project on the hill Srd, describing the project as one which serves only private interests, rather than the public interest of the citizens of Dubrovnik (Dubrovacki.hr 20I0).

Srd is Ours then organized a public debate to discuss the future of the green area on the hill Srd. Figure I shows the initiative's first activist action: a large banner reading "Srd is Ours" was placed on the hill Srd as both a protest and a political statement of the newly formed initiative. With this, the activists clearly stated that the hill Srd is supposed to be a public space for all citizens of Dubrovnik. The banner was placed near the medieval fortress Imperial, also included in the private concession of the area. The activists would later use this in their effort to stop the investor from gaining legal permissions to build the golf resort.

Figure 1: (Photo: Grgo Jelavić/Pixsel in Večernji.hr: http:// www.vecernji.hr/hrvatska/dubrovacki-aktivisti-protivgolf-parka-srdj-je-nas-185736, 27.11.2016).

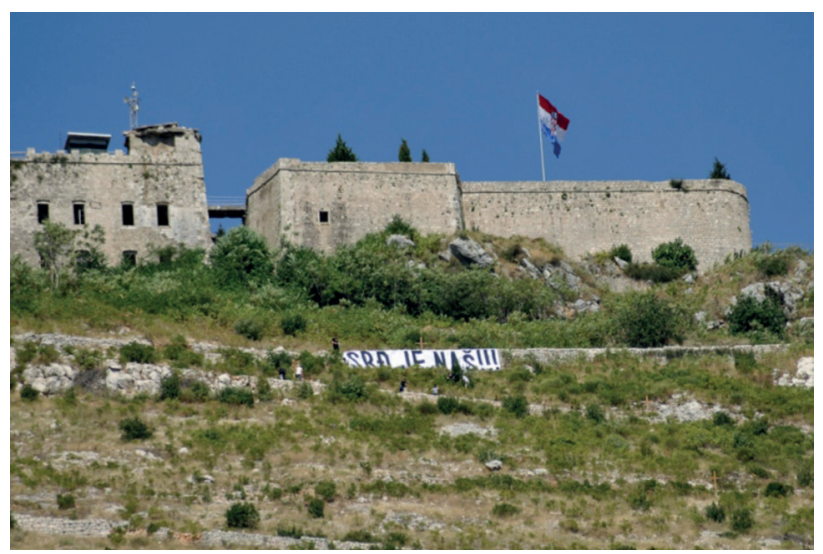

When in September 2010 the city government organized a public debate about the golf resort project in the cinema Freedom, Srđ is Ours activists used this opportunity to increase the initiative's visibility and to promote their political discourse; they again voiced their demand for a referendum (Fulurija 20IO).

As part of Srd is Ours' media strategy, the initiative created their own media content that was disseminated through their web page, Facebook page and a printed newspaper. Contributors included both Srd is Ours activists and experts from various fields, such as architects, ecologists and political scientists. They produced five issues of their newspaper, each printed in 4000 copies and available free of charge. Three issues were published before the referendum campaign; one during the campaign; and the final issue of the newspaper was published in 20I4, following the referendum. The newspaper, along with other media content created by Srd is Ours, both provided information to citizens of $\mathrm{Du}$ brovnik, and served as a platform for articles and texts that problematized the relationship between public and private ownership, the closed political system, and discussed alternative solutions for the future urban development of Dubrovnik and the hill Srd.

\section{Srđ is Ours' Activities and Strategies during the Refer-} endum Campaign

The second phase refers to the period of the referendum campaign, when Srd is Ours called for the organization of the referendum. In November 2012, when it became clear that the local government and the newly elected national government would not hold the referendum on the future of the hill Srd, the initiative decided to start organizing the local referendum themselves. Before starting the official process of organizing that referendum, the initiative organized a public opinion poll (the sample included 400 respondents living in Dubrovnik), in which they asked four specific questions. The results of the survey suggested that the citizens of Dubrovnik were aligned with Srd is Ours activists. The majority of those surveyed did not believe investors' claims that $\mathrm{Du}$ brovnik would benefit from the golf resort project and supported Srd is Ours' activities. The majority of $63 \%$ of respondents did not support the development project on the hill Srd, and $77 \%$ were in favor of organizing a local referendum on the golf resort. Srd is Ours activists then used the public opinion poll results to announce the referendum campaign, to prepare their strategy for the referendum campaign, and to inform the larger public about the results of the public opinion poll (Srd is Ours 20I2, 6-9).

The referendum campaign consisted mostly of regular activities defined by the law that regulates referendums. The activists formed a formal citizens' initiative 
and an organizational committee for the referendum, and they drafted the question that would be asked at the referendum. Additionally, Srd is Ours activists publicly expressed criticism against the Urban Development Plan, and stressed the environmental impact of the golf resort project. During this period, volunteers collected more than 8,000 signatures for the organization of the local referendum.

On 20 February 2013, Srd is Ours held a press conference, announcing that they had collected enough signatures to hold the referendum. The initiative additionally used the press conference to advocate for the referendum to be held on the same day as the 2013 local elections, and to express concern that the local government would want to hold the referendum and the elections on different days.

Public discussions about the economic aspects of building the golf resort in Srd organized by Srd is Ours and the NGO Green Action continued after the signature collection until the local referendum was held. Again, the initiative was trying to inform citizens of $\mathrm{Du}$ brovnik that the golf resort project was destructive both with regard to the environment and with regard to the economy. In fact, Srd is Ours and Green Action even filed legal charges against the Ministry of Environmental and Nature Protection for approving the environmental certificate needed for the Srd golf resort (Srd is Ours 20I4, 4-5).

The initiative also used one particularly interesting strategy to try to exert pressure on local and national governments. Right before voting on the Resolution on Croatian readiness to join the EU in the European Parliament, Srd is Ours and Green Action activists lobbied the green MP Franziska Katharina Brantner to convince other members of the European Parliament to support the amendment considering a more inclusive legal framework of local institutions of direct democracy. Although the alliance which was built between the Green Group in the European parliament and the initiative Srd is Ours did not succeed, the question of building a golf resort on the hill Srd gained visibility in one of the most important EU institution (T.portal.hr/Hina 2OI3a).

\section{Srđ is Ours' Activities and Strategies after the Refer-} endum

After the referendum, Srd is Ours' main strategy was to continue to fight against the project, despite the failed referendum. The activists undertook several different activities-they organized press conferences, where they publicly shamed the corrupt media and political elites, they protested against the Urban Development Plan for the hill Srd, they purchased land on the hill Srd, and they formed a political party called Srd is City to challenge the project in the City Council. However, one of the initiative's most important activities after the referendum was the public protest against the golf resort project they organized in July 2013, when the City Council was to vote for the new Urban Development Plan. This protest was one of the most visible and best-attended protests organized by the initiative. It was also one of the activists' most confrontational moments, given that they blocked the entrance to the Dubrovnik city hall for all City Councilors to prevent them from voting for the Urban Development Plan - the passing of which would be crucial in the realization of the golf resort project. The protest aimed to reveal corrupt politicians and to gain media visibility after the failed referendum (Slobodnadalmacija.hr 20I3).

Srd is Ours organized another press conference after the referendum, where they wanted to convey four main messages. The activists stressed the relative success of the local referendum, given that $84.2 \%$ of voters in the referendum were against the proposed golf resort project. They then addressed the failure of the referendum because it did not satisfy the minimal voter turnout, and accused the political elites and corrupt media of being against the idea of stopping the destructive project and of being responsible for a lack of motivation among the voters to vote in the referendum. The activists also discussed the legal framework governing the local referendum, one that the initiative perceived to be too strict and excluding. Finally, the initiative announced that they would continue to work on the protection of public spaces in Dubrovnik (Srd is Ours 2013a, 2013b).

One of the ways of protecting public spaces and promoting urban development plans that have interests of Dubrovnik's citizens in mind are legal procedures and exertions of pressure against institutions accused of undertaking biased actions in favor of the golf resort project on the hill Srd. One such activity occurred in May 2015, when the initiative publicly warned the Ministry of Environmental and Nature Protection that the environmental certificate for the golf resort was not valid (Dubrovniknet.hr 2015).

In this phase, the initiative also undertook an interesting action inspired by, as activists said, Scottish activists who were protesting against golf courts funded by the investor and US president Donald Trump. More specifically, the NGO Green Action purchased an area of 60 square meters on the hill Srd with the aim of preventing the company "Razvoj golf" from purchasing all of the land on the hill Srd from local owners (Index.hr 20I3).

Finally, several activists of the initiative formed a local political party Srd is City in 2013, to try to influence the development of policies in Dubrovnik, as well as to argue against the golf resort in the City Council. Three councilors from Srd is City were elected into the $\mathrm{Du}$ brovnik City Council. 


\section{Political Opportunity Theory}

Political opportunity, or political process theory, posits that political opportunities are the essential factor in social movements' development and success. Doug McAdam, one of the pioneers in the conceptualization of this theory, argues that solidarity among activist groups and movements, the movement's organizational stage, and external support are key elements in social movements' actions (Kriesi 20I3). More specifically, McAdam suggests that a movement's political opportunity consists of four dimensions - the formal dimension referring to the relative openness or closure of the institutionalized political system; the instability or stability of a broad set of elite alignments that typically undergird a polity; the presence or absence of elite allies; and the state's capacity or propensity for repression (McAdam 1996, 27).

Focusing on the first three of McAdam's dimensions of political opportunity, as well as Kriesi's politicalprocess theoretical concepts, I will analyze the political context of the citizens' initiative Srd is Ours' actions regarding the 2013 referendum in Dubrovnik. More specifically, I will argue that Srd is Ours was influenced by structures of political opportunities and threats in the current Croatian political system. This analysis serves as an example of the relationship between urban social movements and the national political system, as well as the national and local political elites' attitude towards social movements in the context of Southeast Europe and the broader region.

\section{The Formal Dimension of Political Opportunity: The Local Referendum in Dubrovnik}

The local referendum on the construction of the golf resort on the hill Srd presents McAdam's formal dimension of political opportunity. More specifically, in the analysis of the political context surrounding Srd is Ours, the referendum itself is the unit of analysis used to assess the relative openness or closure of the institutionalized political system, as well as the political system's responsiveness to collective actions undertaken by social movements. In other words, the Croatian political system's responsiveness will be assessed through the analysis of the Croatian law regulating local and national referendums (e.g. the required support for the organization of the local referendum and the required voter turnout) and the law on local and regional self-government.

The laws that regulate local referendums in Croatia also regulate all other forms of individual involvement in the local, regional and national political decisionmaking process outside of the conventional process of democratic elections. There are two ways to organize a local referendum. Either the local City Council decides to hold a referendum, or citizens demand a referendum. For such a referendum to be organized, relatively simple procedures need to be followed. The citizens need to form an organizational committee, name their initiative for the referendum, specify the geographic area in which the referendum is supposed to take place (in the context of local referendums), state a clear formulation of the question, and provide a clear explanation of the demands stemming from the referendum question. For a local referendum to be held, at least $20 \%$ of the area's residents need to sign a petition for its organization (Croatian Government 2013).

The only major difference between the local and the national referendum can be found in the regulation of the required voter turnout. While there is no prescribed minimum voter turnout for a national referendum, the local referendum regulations demand a minimum of a $50 \%$ voter turnout for the referendum to be valid (Croatian Government 20I6). Such regulation seems irrational, and it potentially demotivates citizens to organize local referendums or to vote in them (Pereša/Zelić 20I2, I9).

In 2012, Srd is Ours formed an organizational committee and announced the local referendum. The question to be asked in the referendum was: "Do you agree with the Urban Development Plan that will allow the construction of a golf course, along with a tourist residential area (hotel, villas, apartments) on the hill Srd?" Srd is Ours' stated political goal was to stop the construction of a golf resort (Srd is Ours 2013c). In the context of activism in the Croatian national political system, until 2013 Srd is Ours was the sixth activists' initiative that tried to organize a referendum, although it did so on a local level (Wikipedia n.d.). Srd is Ours was the first urban social movement that was supported by the reactivated National Urban Planning Forum - a network of the Right to the City activists from different parts of Croatia. More importantly, it was the first citizen's initiative that introduced a local referendum as their main strategy for achieving their political goals (RTL Website 20I3).

After the failed referendum, intellectuals and activists that supported Srd is Ours turned the focus of their critique towards the biased mass media reporting (Lasić 20I4, 7), the relationship between business and political elites, and the nonresponsive political system (Šalaj 20I4, IO). Srd is Ours activists published criticisms of the golf resort project written by intellectuals, activists and experts in their official newspaper, Srd is Ours (Srd is Ours 2014, 5).

Despite the failed referendum, Srd is Ours continued its activities against the construction of the golf resort. Several of its activists formed the party Srd is City and four were elected into Dubrovnik's City Council in 2013 , where they actively advocated against the golf resort (T.portal.hr/Hina 2013b). The construction of the 
golf resort has not yet started in part due to Srd is City's and other activists' efforts to point to every violation of procedure, using legal actions and the slowness of state bureaucracy. Furthermore, Srd is Ours activists participated in the national referendum campaign We won't give our highways against the monetization of highways (We Wont Give Our Highways Webpage 20I3).

Therefore, Srd is Ours' criticism of the closed political system-primarily focused on contesting institutional regulations of the required voter turnout-was their dominant strategy after the failed referendum. Their general criticism called for a reappraisal of representative democracy, which they proclaimed to be defective, as it does not include efficient direct democracy mechanisms - i.e. all political decisions are in fact made by political elites (Šalaj 20I4, IO).

\section{The Informal Dimension of Political Opportunity: Political Elites' Excluding Strategies and the Role of Allies among the Political Elites}

Apart from using formal strategies to enter the political arena (i.e. referendums), social movements can also make use of cultural models (Kriesi 20I3) or informal political opportunities. Specifically, informal political opportunities are structures that are not institutionalized. In other words, they represent the dynamics between political elites and urban social movements - the instability or stability of a broad set of elite alignments that typically undergird a polity, and the presence or absence of elite allies (McAdam I996, 27).

In the context of Srd is Ours, the first aspect of informal political opportunities can be found in the dynamics between the initiative and the local government. Specifically, the centre-left local government broke its pre-election promise to organize the local referendum; political elites refused to hold the referendum concurrently with the local elections for the mayor and members of the City Council; and finally, a coalition between local independent list of voters, moderate left, liberal and rightwing political parties, known as Dubrovnik Deal, was formed in the Dubrovnik City Council. The second aspect of informal political opportunities refers to the dynamics between specific City Council members and Srd is Ours.

\section{Key Components of Political Elites' Excluding Strate- gies}

The first indicator of political elites' excluding strategies-i.e. closure of the political system - can be traced back to the local government's 2oro decision to not hold a referendum about the golf resort project on Srd. More specifically, as part of his pre-election campaign, mayor candidate Andro Vlahušić, supported by a moderate left coalition (the Social-Democratic Party and the liberal Croatian People's Party), promised to hold a local referendum in Dubrovnik. However, once he was elected mayor, he and his newly-formed centre-left coalition decided to not hold the referendum. In fact, the new local government had almost the same stance towards Srd is Ours and the local referendum as did the previous centre-right government and the mayor Dubravka Šuica. The new government favored the constructional project on the hill Srd, while practicing excluding strategies towards the local urban social movement-in reality, blocking their demands for a local referendum (Capor/ Cvijetić 2OI2).

The second indicator that points to the existence of a set of elite alignments that undergird a closed political system is the formation of a coalition of political parties known as the Dubrovnik Deal. After the 2013 local elections in Dubrovnik, not one party or coalition of parties had a majority of seats in the City Council. Dubrovnik Deal was then formed in July 2013 as a cooperation agreement between the moderate left SDP, the right-wing HDZ, the liberal HNS, and Pero Vićan's local electoral list, consisting of independent candidates. Although this appears to be an uncommon coalition of political parties which, on the national level, are considered to be political rivals, the mayor of Dubrovnik, Andro Vlahušić, clearly stated that the deal was formed for "new investments and new jobs"-including the golf resort on the hill Sra-for the citizens of Dubrovnik. After the referendum and local elections, the newly-formed Dubrovnik Deal voted for the Urban Development Plan, which was one of the crucial documents needed for the legalization of the development project on the hill Srd (Dubrovacki.hr 20I3).

The third indicator of a lack of a political will to include the social movement in the political decisionmaking process is the local government's refusal to hold the local referendum concurrently with the 2013 local elections in Croatia, which later proved to be one of the key elements in the failure of the referendum. The political elites' exclusionary strategies towards Srd is Ours were particularly visible in 2013, when, just before the local elections in Dubrovnik, then president of the Dubrovnik City Council Olga Muratti, along with other ruling City Councilors, denied Srd is Ours's demands to hold a local referendum on I9 May 20I3, the day of the local elections in Dubrovnik and the rest of Croatia. The City Council decided to hold the referendum three weeks before the local elections, on 28 April 20I3, which led to a lower voter turnout-only $30.5 \%$ of residents voted in the referendum ( $\mathrm{Srd}$ is Ours 20I4, 5), compared to $49.49 \%$ who voted in the elections for the local government (Izbori.hr 20I3). Hypothetically speaking, had the local referendum been held on the same day as the 2013 local elections in Dubrovnik, one could argue that the 
local referendum would have succeeded because of the almost fifty percent voter turnout on local elections and thirty percent of highly motivated citizens that voted on local Srd is Ours referendum.

According to Srd is Ours, all three indicators can be explained through the alignment of business and political elites, or, more specifically, good relations between the businessman Frenkel and Croatian national and local elites. Srd is Ours has accused political elites of having "too close a relationship with Frenkel," considering that the former presidents Ivo Josipović met with Frenkel several times during his term (Srd is Ours 20Irb, I4), the former president of the Republic of Croatia Stjepan Mesić proclaimed Frenkel an honorary consul to Croatia in Israel (Srd is Ours 20IIc, II), and Croatian daily newspaper Večrnji list also insinuated, which was then used by the initiative, that the former Croatian prime minister Ivo Sanader (Croatian Democratic Union, $\mathrm{HDZ}$ ) was involved in a corruption scandal with the same investor. Dubrovnik mayor Andro Vlahušić (Croatian People's Party, HNS) was also accused of having a special relationship with the investor (Srd is Ours 2OI2, 6-9), and the ministers in the moderate left government (SDP, HNS, IDS, HSU) were accused of having a pro-business stance, considering that they backed the golf resort project and pro-business legislation, such as the law of strategic investments that excludes several democratic processes in the approval of investments (Srd is Ours 2OI4, 5).

\section{The Role Of Allies Within The Political Elites}

McAdam (1996) posits that the presence of social movements' allies within the political and economic elites represents the second informal dimension of a social movement's political opportunities. In the context of Srd is Ours, presence, and absence, of such allies is illustrated by the City Council's voting for the Urban Development Plan. More specifically, those City Councilors who, on 30 July 2013, voted against the Urban Development Plan can be seen as allies of the Srdis Ours initiative. Three of them were members of a parliamentary political party (Croatian Labour Party, HL), one was a member of a national political party (Croatian Social Liberal Party, HSLS), and another three were members of the newly formed local political party Srd is City. Following the Dubrovnik Deal, I6 City Councilors voted for the Urban Development Plan. The council thus adopted the plan, despite the protest of Srd is Ours and seven City Councilors' votes against the plan (Dnevnik.hr 20I3).

The voting process showed that Srd is Ours received support from only a minority among the political elites in Dubrovnik. However, a more influential support came from the Ministry of Environmental and Nature Protection during 20II and 20I2. The minister Mirela Holy refused to approve the environmental impact study for the golf resort and had repeatedly said that she was not in favor of the golf resort (Srdis Ours 2012, 7). However, after Holy's resignation in 2012, the new minister Mihael Zmajlović approved the impact study needed for the construction of the golf resort.

To summarize, although elite allies-members of political parties and the Ministry of Environmental and Nature Protection-did indeed support Srd is Ours, their support was either inconsistent, as the new minister decided to back the construction project on Srd, or it was insufficient, as there were too few Srd is Ours' supporters in the City Council. Thus, elite allies failed to improve the initiative's odds of achieving their political goal; they failed to influence local and national policies.

\section{Conclusions}

In this paper, Srđ is Ours' referendum campaign was used as an example in the analysis of urban social movements' political opportunities to influence national and local policies. The urban social political movement Srd is Ours in Dubrovnik was a part of the larger network of the Right to the City movement in Croatia. It was original in two ways-it was the first Right to the City movement in Croatia initiated outside of the capital city of Zagreb, and it was the first urban social movement in Croatia that used the local referendum as their political strategy to influence local and national policies.

All five events-the referendum, the broken preelection promise, the Dubrovnik Deal, the City Council's refusal to hold the referendum along with the 2013 local elections, and the short-term support from the Ministry of Environmental and Nature Protection as well as seven City Councilors voting against the Urban Development Plan for the golf resort-analyzed through McAdam's (1996) classification of formal and informal dimensions of political opportunities, indicate that formally and informally the Croatian national political system is closed in terms of allowing social movements to influence policies. In the context of formal dimensions of political opportunities, in order to be valid, the institution of direct democracy-the local referendum-requires a high voter turnout. In the context of informal political opportunities, stability of a broad set of alignments that undergird polity was found in the following events: the centre-left government's broken pre-election political promises to hold the local referendum; the $\mathrm{Du}$ brovnik Deal-an uncommon right-left coalition in the City Council that supported the construction of the golf resort; and the excluding strategies of the ruling City Councilors towards Srd is Ours' demand to hold the local referendum concurrently with the local elections in May 2013-which was Srd is Ours' strategy to ensure that the regulation of a high voter turnout would be satisfied. 
With regard to the presence of elite allies, Srd is Ours' political allies were not able to mobilize a large enough number of their supporters, most likely due to their low political influence on the local and the national level. Furthermore, Srd is Ours' allies in the City Councilmembers of three political parties who voted against the Urban Development Plan that favors the construction of the golf resort-and inconsistent support from the Ministry of Environmental and Nature Protection were not sufficient to aid Srd is Ours in their effort to influence local policies.

According to McAdam's classification of dimensions of political opportunities, Srd is Ours acted within the context of a closed political system-both with regard to the formal institution of a local referendum and with regard to local and national political elites' excluding strategies directed towards the initiative's demands and political goals. Therefore, political elites' activities on the national level (i.e. high required voter turnout for the local referendum), and their activities on the local level (i.e. excluding strategies) can be seen as authoritarian towards social movements in Croatia.

The rapid neoliberalization that is prevalent in the region of Eastern Europe has led to the initiation of counter protests, or more specifically to the formation of different social movements in this region. The Croatian context is therefore typical of this region-the political system appears to be authoritarian, political elites introduce top-down policies, and the economy appears to be going through the process of neoliberalization; the latter is visible in terms of both privatization and the introduction of pro-business legislation influenced by closer ties between the business sector and the government and the general neoliberal context of Eastern Europe today.

Srd is Ours' actions also had a broader political impact on the relations among political forces in the country. For example, it raised national visibility of civil society in the media, and in fact was the most successful activist campaign organized outside of the political, cultural and economic center of Croatia, the capital Zagreb. Furthermore, the work of Srd is Ours contributed to the development of democracy, both at the local level and in Croatia. The referendum in Dubrovnik was the first local referendum organized in Croatia, and it can be argued that its successful organization inspired later referendum campaigns and progressive platforms on the national level.

However, the exact consequences of the Right to the City collective actions for the Croatian political system remain to be seen. At this moment, it can be argued that their actions effected change in the Croatian informal political system, in the area of activism. More specifically, Srd is Ours, along with the referendum campaign We won't give our highways and We won't give Varšavska, led to the creation of a broader national platform We won't give Ours. Although it still remains unclear if and how these changes will affect the Croatian political system, one thing is certain: "business as usual" in this rather young democratic political system is changing.

This case study fits well into a wider international context of social movements' efforts to democratize political systems. As distrusts with business-as-usual politics in combination with established political parties is evident no matter the geopolitical context of the political systems, this case study can contribute to a better understanding of how closed political systems function and how social movements and initiatives can develop different strategies to combat it.

\section{References}

Biliškov, Nikola (2013). To je Pula kakvu volim! (That is Pula I love!). An article from website $\mathrm{H}$-alter.org, $\mathrm{Za}-$ greb. Internet: http://www.h-alter.org/vijesti/to-jepula-kakvu-volim (Accessed: July 27, 2016).

Capor, Đuro/Srdjana Cvijetić (2012). Gdje smo stali i što nas čeka? (Where we are now and what is next?). Srd Is Ours Official newspapers, Citizens' Initiative Srd je naš, Dubrovnik, No. 3, 2.

Cepić, Dražen/Marko Kovačić (2015). Civil Society Going Political: The Crisis of Democracy and the Rise of Participatory Political Parties in Croatia, in: Florian Bieber/Armina Galijaš/Hrvoje Paić/Robert Pichler (eds.): Contemporary Southeastern Europe, Graz, 24-44.

Croatian Government (2013). Zakon o lokalnoj i područnoj (regionalnoj) samoupravi (Law on local and regional self-government), Official Gazette No. 33/oI, 60/oI, I29/05, I09/07, I25/08, 36/09, 36/09, I50/II, I44/I2, I9/13.

Croatian Government (2016). Zakon o referendumu i drugim oblicima osobnog sudjelovanja u obavljanju državne vlasti i lokalne i područne (regionalne) samouprave (The Law on Referendum and Other Citizens' Individual Involvement in Performing Local, Regional and National Self-government), Official Gazette No. 33/96, 92/or, 44/o6, 58/o6, 69/o7, 38/o9.

Ćimić, Ilko (2010). Tajne dubrovačkog golfa: Tko je zapravo investitor Aaron Frenkel? (The secrets of golf in Dubrovnik: Who is investor Aaron Frenkel really?), in: Index.hr. Internet: http://www.index.hr/vijesti/ clanak/tajne-dubrovackog-golfa-tko-je-zapravoinvestitor-aaron-frenkel/5I4793.aspx (Accessed: October 28, 2015).

Dnevnik.hr (2013). HSLS: 'Dubrovački dogovor' je koalicija kojoj Dubrovnik nije u interesu (HSLS: 'Dubrovnik Deal' is a coalition that does not have Dubrovnik in mind). Internet: http://dnevnik.hr/vijesti/hrvatska/ 
hsls-dubrovacki-dogovor-je-koalicija-kojoj-dubrovnik-nije-u-interesu---295160.html (Accessed: September 22, 2015).

Dolenec, Danijela/Karin Doolan/Tomislav Tomašević (2015). Metamorphoses and Meaningfulness: The Right to the City Movement in Croatia, Paper presented at the conference "Resistance or Resilience? New Avenues of Activist Citizenship in Southeast Europe", London, I-27.

Dubrovacki.hr (20I0). Dubrovačke udruge za borbu protiv golfera dobile pojačanje iz Zagreba (Dubrovnik NGOs gained reinforcement from Zagreb against golfers). Internet: http://dubrovacki.hr/clanak/2227o/srd-jenas (Accessed: November 27, 2015).

Dubrovacki.hr (2013). Dubrovački dogovor okupio 16 vijećnika iz HDZ-a, HNS-a iSDP-a te njihovih partnera (Dubrovnik Deal gathered I6 councilors from HDZ, HNS, and SDP, and their partners). Internet: http:// dubrovacki.hr/clanak/53609/dubrovacki-dogovorokupio-I6-vijecnika (Accessed: September 22, 2015).

Dubrovniknet.hr (2015). Golferima ističu rokovi - Studija o utjecaju na okoliš više ne vrijedi (Golfers deadlines are passed - environmental study is not valid anymore). Internet: http://www.dubrovniknet.hr/ novost.php?id=37189\#.VlsTzHr5LVP (Accessed: November 27, 2015).

Fulurija, Emir (2010). Dubrovački aktivisti protiv golfparka: "Srđ je naš!" (Activists from Dubrovnik against golf park: "Srđ is Ours!", in: Večernji.hr. Internet: http://www.vecernji.hr/hrvatska/dubrovackiaktivisti-protiv-golf-parka-srdj-je-nas-I85736 (Accessed: November 27, 2015).

H-alter.org (20I3). Srđ je vaš, Marjan je naš! Trbina u Spli$\mathrm{tu}$ (Srd is yours, Marjan is ours! Public discussion in Split). Internet: http://www.h-alter.org/vijesti/srdjje-vas-marjan-je-nas-tribina-u-splitu (Accessed: July 28,2016$)$.

Index.hr (20I3). Zelena akcija kupila 60 kvadrata Srđa: osigurala status stranke ako počne izvlašćivanje privatnih vlasnika (NGO Green Action bought 60 square meters of Srd). Internet: http://www.index. $\mathrm{hr} /$ vijesti/clanak/zelena-akcija-kupila-6o-kvadratasrdja-osigurali-status-stranke-ako-pocne-izvlascivanje-privatnih-vlasnika/6749ı2.aspx (Accessed: November 29, 2015).

Izborihr (2013). Privremeni Neslužbeni Rezultati za lokalne Izbore. Internet: http://www.izbori.

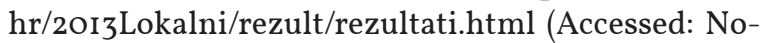
vember 29, 2015).

Kriesi, Hanspeter (2013). Društveni pokreti, in: Daniele Caramani (ed.): Komparativna politika, Zagreb, 29I308.

Lasić, Ivan (2014). Igra je namještena (The Game Is Set). Srd Is Ours Official newspapers, Citizens' Initiative Srđ je naš, Dubrovnik, No. 5, 7-9.
Mayer, Margit (2012). The "Right to the City" in Urban Social Movements, in: Neil Brenner/Peter Marcuse/ Margit Mayer (eds.): Cities For People, Not For Profit: Critical Urban Theory and The Right to the City, London/New York, 63-85.

McAdam, Doug (1996). Conceptual Origins, Current Problems, Future Directions, in: John D. McCarthy/ Mayer N. Zald/Doug McAdam (eds.): Comparative Perspectives on Social Movements: Political Opportunities, Mobilizing Structure and Cultural Framing, Cambridge, 23-40.

Mrakovčić, Matija (2016). Obrana zajedničkih dobara (Defending the commons), in: Kulturpunkt.hr. Internet: http://www.kulturpunkt.hr/content/obrana-zajednickih-dobara (Accessed: 28.7.2016).

Nikolić, Leo (20II). Ne zidajte koalicije na Marjanu! (Don't build coalitions on Marjan!), in: Tportal.hr. Internet: http://www.tportal.hr/vijesti/hrvatska/I62365/Nezidajte-koalicije-na-Marjanu.html (Accessed: July 27, 2016).

Pereša, Irena/Dragan Zelić (2012). Analiza referenduma u Hrvatskoj u odnosu na europske standarde (Comparative Analysis of the Referendums Rules in Croatia with European standards), GONG, Zagreb, I-27.

RTL Website (20I3). Povijesni uspjeh Dubrovčana: sakupili potpise za referendum (Historic success of $\mathrm{Du}$ brovnik citizens: they collected enough signatures for the referendum), in: Vijestirtl.hr. Internet: http:// www.vijesti.rtl.hr/novosti/653574/povijesni-uspjehdubrovcana-sakupili-potpise-za-referendum/ (Accessed: July 28, 2016).

Slobodnadalmacija.hr (20I3). Usvojen UPU platoa Srđ: više nema prepreka za početak investicije u kompleks s golfom (Urban development plan for plateau Srd accepted: There are no more obstacles). Internet: http:// www.slobodnadalmacija.hr/Dubrovnik/tabid/75/articleType/ArticleView/articleId/217199/Default.aspx (Accessed: September I9, 2015).

Srđ Is Ours (2011a). Zašto je Srđ naš? (Why is Srđ Ours?). Official newspapers of the Citizens' Initiative Srd je naš, Dubrovnik, no. I, 2.

Srd Is Ours (20Irb). Kronika (Chronicle). Official newspapers of the Citizens' Initiative Srđ je naš, Dubrovnik, No. I, I4.

Srd Is Ours (20IIc). Kronika (Chronicle). Official newspapers of the Citizens' Initiative Srd je naš, Dubrovnik, No. I, II.

Srd Is Ours (2012). Kronika (Chronicle). Official newspapers of the Citizens' Initiative Srđ je naš, Dubrovnik, No. 3, 6-9.

Srd is Ours (2013a). Public Statement After The Referendum. Internet: http://dubrovnikreferendum.com/ index.php/referendumsko-pitanje-objasnjenje (Accessed: September 22, 2015). 
Srd is Ours (20I3b). Results of the local referendum in Dubrovnik April 28, 20I3. Internet: http://www. dubrovnikreferendum.com/index.php/vijesti/283rezultati-referenduma-u-dubrovniku-28-04-20I3 (Accessed September 22, 2015).

Srd is Ours (2013c). The Referendum Question Explained. Internet: http://dubrovnikreferendum.com/index. php/referendumsko-pitanje-objasnjenje (Accessed: September 22, 2015).

Srd Is Ours (20I4). Kronologija (Chronology). Official newspapers of the Citizens' Initiative Srd je naš, Dubrovnik, No. 5, 4-5.

Šalaj, Berto (2014). Zašto je u Hrvatskoj 84 manje od 66 ? (Why is 84 less than 66 in Croatia?), in: Srd Is Ours (ed.): Official newspaper, Dubrovnik, No. 5, IO-II.

T.portal/Hina.hr (20I3a). Nije prihvaćen amandman o Srdu u Europskom parlamentu (The amandment on Srd was not adopted). Internet: http://www.tportal. $\mathrm{hr} /$ vijesti/svijet/256163/Nije-prihvacen-amandmano-Srdu-u-Europarlamentu.html (Accessed: November 27, 2015).

T.portal/Hina.hr (2013b). Dio članova inicijative 'Srđ je naš' izlazi na lokalne izbore (Several members of the initiative Srd is ours are running at local elections). Internet: http://www.tportal.hr/vijesti/hrvatska/ 258709/Dio-clanova-inicijative-Srd-je-nas-izlazina-lokalne-izbore.html (Accessed: September I9, 2015).

We Wont Give Our Highways (2013). Official Webpage. Internet: http://referendum-autoceste.hr/ (Accessed: November 28, 2015).

Wikipedia (n.d.). Referendums in Croatia. Internet: https://hr.wikipedia.org/wiki/Referendum\# Referendumi_u_Hrvatskoj (Accessed: September I8, 2015).

\section{Author}

Nikola Zdunić, born in 1990, received his Bachelor and Master degrees at the University of Zagreb, from the Faculty of Political Science. His research currently focuses on urban social movements in Eastern Europe. $\mathrm{He}$ is especially interested in the influence of political systems on social movements' political goals, which he analyzed and compared in his Master thesis "Urban Activism for Public Space: A Comparative Case Study of Srd is Ours and 100\% Tempelhofer Feld." In November 2015, the IOO\% Tempelhofer Feld case study was also presented at the conference "Climate Justice: Perspectives from Natural and Social Sciences" at the Institute for Political Ecology in Zagreb. 